\title{
T-Type Calcium Channel Inhibition Underlies the Analgesic Effects of the Endogenous Lipoamino Acids
}

\author{
Guillaume Barbara, ${ }^{1}$ Abdelkrim Alloui, ${ }^{2,3}$ Joël Nargeot, ${ }^{1}$ Philippe Lory, ${ }^{1}$ Alain Eschalier,,${ }^{2,3}$ Emmanuel Bourinet, ${ }^{1}$ \\ and Jean Chemin ${ }^{1}$ \\ 'Département de Physiologie, Institut de Génomique Fonctionnelle, Centre National de la Recherche Scientifique Unité Mixte de Recherche (UMR) 5203, \\ INSERM U661, Universités de Montpellier, 34094 Montpellier, France, and ${ }^{2}$ INSERM, UMR 766, and ${ }^{3}$ Clermont Université, Laboratoire de Pharmacologie \\ Médicale, Faculté de Médecine, F-63000 Clermont-Ferrand, France
}

Lipoamino acids are anandamide-related endogenous molecules that induce analgesia via unresolved mechanisms. Here, we provide evidence that the T-type/Cav3 calcium channels are important pharmacological targets underlying their physiological effects. Various lipoamino acids, including $\mathrm{N}$-arachidonoyl glycine (NAGly), reversibly inhibited Cav3.1, Cav3.2, and Cav3.3 currents, with potent effects on Cav3.2 [ $\mathrm{EC}_{50} \sim 200 \mathrm{~nm}$ for $N$-arachidonoyl 3- $\mathrm{OH}-\gamma$-aminobutyric acid (NAGABA-OH)]. This inhibition involved a large shift in the Cav3.2 steady-state inactivation and persisted during fatty acid amide hydrolase (FAAH) inhibition as well as in cell-free outside-out patch. In contrast, lipoamino acids had weak effects on high-voltage-activated (HVA) Cav1.2 and Cav2.2 calcium currents, on Nav1.7 and Nav1.8 sodium currents, and on anandamide-sensitive TRPV1 and TASK1 currents. Accordingly, lipoamino acids strongly inhibited native Cav3.2 currents in sensory neurons with small effects on sodium and HVA calcium currents. In addition, we demonstrate here that lipoamino acids NAGly and NAGABA-OH produced a strong thermal analgesia and that these effects (but not those of morphine) were abolished in Cav3.2 knock-out mice. Collectively, our data revealed lipoamino acids as a family of endogenous T-type channel inhibitors, suggesting that these ligands can modulate multiple cell functions via this newly evidenced regulation.

\section{Introduction}

T-type calcium channels (T-channels) have important roles in cell excitability and calcium signaling, contributing to a wide variety of physiological functions. In the nervous system, T-channels are implicated in spontaneous firing (Perez-Reyes, 2003), slow-wave sleep (Lee et al., 2004), epilepsy (Kim et al., 2001; Becker et al., 2008), pain perception (Todorovic et al., 2001; Bourinet et al., 2005; Choi et al., 2007; Nelson et al., 2007a), and differentiation (Chemin et al., 2002). Three T-channel subunits have been identified: Cav3.1, Cav3.2, and Cav3.3 (Perez-Reyes, 2003), which are implicated in distinct physiological functions, as recently supported by knock-out (KO) mice studies (Kim et al., 2001; Chen et al., 2003; Lee et al., 2004; Mangoni et al., 2006; Choi et al., 2007). Over the past few years, intracellular messenger pathways (Wolfe et al., 2003; Chemin et al., 2006; Park et al., 2006; Chemin et al., 2007b;

Received June 19, 2009; accepted July 27, 2009.

This work was supported by Centre National de la Recherche Scientifique, ANR-2005-Neuro31, ANR-2006Neuro35, Institut UPSA de la douleur, Association Francaise contre les Myopathies, Fédération pour la Recherche sur leCerveau, and Association pour la Recherche sur le Cancer/Institut national du cancer (ARC Inca). We thank Dr. Kevin Campbell for the generous gift of the Cav3.2 $\mathrm{K} 0$ mice, Dr. Terrance Snutch for plasmids encoding the Cav1.2, Cav2.2, $\alpha 2-\delta 1$, and $\beta 2$ subunits, Dr. Amanda Patel for the plasmid encoding TASK1, Drs. Norbert Klugbauer, John N. Wood, and GeoffC. Woods for plasmids encoding Nav1.7 and Nav1.8, Dr. Antonio Ferrer-Montiel for the plasmid encoding TRPV1, and Dr. Edward Perez-Reyes for Cav3.2(H191Q). We are grateful to C. Barrère and I. Bidaud for technical assistance. We are grateful to Fondation de la Recherche Médicale for the fellowship to G.B. We thank Thomas Moore-Morris for careful reading of the manuscript.

Correspondence should be addressed to Jean Chemin, Département de Physiologie, Institut de Génomique Fonctionnelle, Centre National de la Recherche Scientifique Unité Mixte de Recherche 5203, INSERM U661, Universités de Montpellier, 34094 Montpellier, France. E-mail: jean.chemin@igf.cnrs.fr.

DOI:10.1523/JNEUROSCI.2919-09.2009

Copyright $\odot 2009$ Society for Neuroscience 0270-6474/09/2913106-09\$15.00/0
Hildebrand et al., 2007; Iftinca et al., 2007; Tao et al., 2008) and endogenous ligands (Nelson et al., 2007a,b; Traboulsie et al., 2007; Maeda et al., 2009) regulating Cav3 activity were identified, including bioactive lipids (Chemin et al., 2001, 2007a; Ross et al., 2008, 2009).

These bioactive lipids, as exemplified with anandamide [ $\mathrm{N}$-arachidonoyl ethanolamide (NAEA)] and $\mathrm{N}$-arachidonoyl dopamine (NADA), also interact with other targets, mainly G-protein-coupled receptors (GPCRs), including cannabinoid (CB) receptors (Devane et al., 1992; Bisogno et al., 2000) and ion channels, including TRPV1 (Zygmunt et al., 1999; Huang et al., 2002; De Petrocellis and Di Marzo, 2009), which prevents unraveling the contribution of Cav3 modulation in their physiological effects. Recently, a new class of signaling molecules, the lipoamino acids, was identified in mammalian tissues (Huang et al., 2001; Bradshaw and Walker, 2005; Milman et al., 2006). The prototype of this class of endogenous lipids, $\mathrm{N}$-arachidonoyl glycine (NAGly), was found at relatively high levels in various tissues, including brain, spinal cord, intestine, kidney, blood, and skin (Huang et al., 2001). NAGly is closely related to the endocannabinoid NAEA and displays cannabimimetic properties, including anti-nociceptive effects (Huang et al., 2001; Burstein et al., 2002; Bradshaw and Walker, 2005; Burstein, 2008; Succar et al., 2007; Vuong et al., 2008). However, this endogenous molecule, which differs from NAEA by a single oxygen moiety (see Fig. $1 C$ ), activates neither known cannabinoid receptors nor the thermosensitive TRPV1 (Sheskin et al., 1997; Huang et al., 2001; Bradshaw and Walker, 2005; Burstein, 2008) and therefore NAGly displays analgesic effects via unresolved mechanisms. In this context, it is interesting to note that we have previously identified that NAEA is a 
T-channel blocker, especially of Cav3.2 (Chemin et al., 2001, 2007a), which supports T-currents in sensory neurons and participates in the transmission of nociceptive stimuli (Todorovic et al., 2001; Bourinet et al., 2005; Choi et al., 2007; Nelson et al., 2007a). Considering that lipoamino acids and T-channel activity are linked to overlapping physiological responses, we hypothesized that lipoamino acids might regulate T-channels to mediate their analgesic effects.

\section{Materials and Methods}

Cell culture and transfection protocols. tsA-201 cells were cultivated in DMEM supplemented with GlutaMax and 10\% fetal bovine serum (Invitrogen). tsA-201 cell transfection was performed using jet-PEI (QBiogen) with a DNA mix containing $0.5 \%$ of a GFP plasmid and $99.5 \%$ of either of the plasmid constructs that code for human Cav3.1a, Cav3.2, and Cav3.3 T-channel isoforms, human TASK-1, human Nav1.7, and human TRPV-1. Cav1.2 and Cav2.2 were transfected in the same conditions with a mix containing the $\alpha 2-\delta 1$ and $\beta 2$ subunits in a (2:1:1 ratio). To obtain efficient expression of Nav1.8 currents we used the F11 cells, a cell line derived from neuroblastoma $\times$ dorsal root ganglion $(D R G)$ neurons. F11 cells were cultivated in Ham's F-12 (Invitrogen) supplemented with GlutaMax, 15\% fetal bovine serum, $2 \%$ hypoxanthine/aminopterin/thymidine (Invitrogen), and $200 \mu \mathrm{g} / \mathrm{ml}$ cis-4-hydroxy-L-proline (Sigma). F11 cell transfection was performed as above using plasmid encoding human Nav1.8. Two days after transfection, tsA-201 and F11 cells were dissociated with Versen (Invitrogen), and plated at a density of $\sim 35 \times 10^{3}$ cells per $35 \mathrm{~mm}$ Petri dish for electrophysiological recordings.

Electrophysiological recordings. Macroscopic currents were recorded at room temperature using an Axopatch 200B amplifier (Molecular Devices). For whole-cell experiments on recombinant calcium and sodium channels, the extracellular solution contained the following (in mM): 135 $\mathrm{NaCl}, 20 \mathrm{TEACl}, 2 \mathrm{CaCl}_{2}, 1 \mathrm{MgCl}_{2}$, and 10 HEPES (pH adjusted to 7.25 with $\mathrm{KOH}, \sim 330 \mathrm{mOsm}$ ) and the internal solution contained the following (in mM): $140 \mathrm{CsCl}, 10$ EGTA, 10 HEPES, 3 Mg-ATP, 0.6 GTPNa, and $3 \mathrm{CaCl}_{2}$ (pH adjusted to 7.25 with $\mathrm{KOH}, \sim 315 \mathrm{mOsm}$ ). Same solutions were used for outside-out experiments, excepted that the intracellular medium contained no Mg-ATP and no GTPNa. For experiments with recombinant TASK1 channel, TEACl was substituted by $\mathrm{NaCl}$ in the extracellular solution and $\mathrm{CsCl}$ by $\mathrm{KCl}$ in the internal solution. Borosilicate glass pipettes have a typical resistance of 1.5-2.5 M $\Omega$. Recordings were filtered at $2-5 \mathrm{kHz}$. Data were analyzed using pCLAMP9 (Molecular Devices), and GraphPad Prism (GraphPad) software. Drugs were applied by a gravity-driven homemade perfusion device and control experiments were performed using the solvent alone. Results are presented as the mean \pm SEM, and $n$ is the number of cells used.

$D R G$ neurons. Lumbar DRGs with attached roots were dissected from adult male C57BL/6J mice and were collected in Neurobasal A medium (Invitrogen) with 10\% heat-inactivated horse serum. DRGs were treated with $2 \mathrm{mg} / \mathrm{ml}$ collagenase (Boehringer Mannheim) for $40 \mathrm{~min}$ at $37^{\circ} \mathrm{C}$, washed in Neurobasal $\mathrm{A} / 10 \%$ horse serum, and taken up in $2 \mathrm{ml}$ of Neurobasal B27 supplemented with GlutaMax and $25 \mathrm{ng} / \mathrm{ml}$ nerve growth factor (Invitrogen). Single-cell suspensions were obtained by six to eight passages through a reduced fire-polished Pasteur pipette tip. Cells were plated on dishes coated with $500 \mu \mathrm{g} / \mathrm{ml}$ polyornithine and 5 $\mu \mathrm{g} / \mathrm{ml}$ laminin. Patch-clamp recordings were performed 3-28 h after plating. For calcium current recordings in DRG neurons, the extracellular solution contained the following (in mM): 130 TEACl, $5 \mathrm{KCl}, 2 \mathrm{NaCl}$, $2 \mathrm{CaCl}_{2}, 1 \mathrm{MgCl}_{2}, 10$ glucose, and 10 HEPES (pH adjusted to 7.25 with $\mathrm{TEAOH}, \sim 330 \mathrm{mOsm}$ ) and the internal solution contained the following (in mM): $130 \mathrm{CsCl}, 10$ EGTA, 10 HEPES, $4 \mathrm{Mg}$-ATP, 0.3 TrisGTP, and 2 $\mathrm{CaCl}_{2}$ ( $\mathrm{pH}$ adjusted to 7.2 with $\mathrm{NaOH}, \sim 300 \mathrm{mOsm}$ ). For experiments on total sodium currents, the extracellular solution contained the following (in mM): $100 \mathrm{TEACl}, 30 \mathrm{NaCl}, 5 \mathrm{KCl}, 1 \mathrm{CaCl}_{2}, 1 \mathrm{MgCl}_{2}, 10$ glucose, and 10 HEPES ( $\mathrm{pH}$ adjusted to 7.25 with TEAOH, $\sim 310 \mathrm{mOsm}$ ). For experiments on TTX-resistant sodium currents, the extracellular solution contained the following (in $\mathrm{mM}$ ): $70 \mathrm{TEACl}, 60 \mathrm{NaCl}, 5 \mathrm{KCl}, 1 \mathrm{CaCl}_{2}$, $1 \mathrm{MgCl}_{2}, 10$ glucose, and $10 \mathrm{HEPES}$ ( $\mathrm{pH}$ adjusted to 7.25 with TEAOH, $\sim 310 \mathrm{mOsm}$ ). Experiments on sodium currents were performed in the presence of $10 \mu \mathrm{M} \mathrm{La}^{3+}$, a calcium channel blocker. TTX-resistant sodium current were isolated using $0.5 \mu \mathrm{M}$ TTX. The internal solution used to record sodium current contained the following (in $\mathrm{mM}$ ): $140 \mathrm{CsCl}, 10$ EGTA, 10 HEPES, $3 \mathrm{Mg}$-ATP, $0.6 \mathrm{GTPNa}$, and $3 \mathrm{CaCl}_{2}$ (pH adjusted to 7.25 with $\mathrm{KOH}, \sim 315 \mathrm{mOsm})$.

Intracellular calcium measurements. Two days after transfection, cells were dissociated with Versen (Invitrogen), and plated at a density of $5 \times$ $10^{4}$ cells per well on polyornithine-coated 96-well plates for Fluo4-AM calcium measurements. The 96-well plates were washed three times in HBSS. Cells were then incubated in HBSS supplemented with $100 \mu \mathrm{g} / \mathrm{ml}$ pluronic acid) and $1 \mu \mathrm{M}$ Fluo4-AM (Invitrogen) for $1 \mathrm{~h}$ at $37^{\circ} \mathrm{C}$. Following the incubation, cells were washed twice with HBSS. Intracellular calcium measurements were performed on a fluorescence plate reader (FlexStation II, Molecular Devices) and drugs were applied at $2 \times$ using a fluid handling integrated device. All measurements were performed in triplicate at $30^{\circ} \mathrm{C}$.

Behavioral studies. Cav3.2 KO mice were obtained from Kevin Campbell, Howard Hughes Medical Institute, University of Iowa, Iowa City, IA (Chen et al., 2003) and maintained in the C57BL/6J background. The animals were housed in groups of 6 per cage with ad libitum access to food and water. The behavioral experiments were performed on male mice, blind to the genotype. Thermal nociception was tested by measuring paw withdrawal latency (PWL) elicited by immersion of the right hindpaw into a $46^{\circ} \mathrm{C}$ hot-water bath (with a cutoff set at $30 \mathrm{~s}$ ). The scores of two separate PWL determinations were averaged as basal control preinjection values. Careful attention was taken to ensure that the ambient temperature was maintained at $22-23^{\circ} \mathrm{C}$. In these experiments $200 \mu \mathrm{g}$ of NAGly, NAGABA-OH, and morphine or $100 \mu \mathrm{g}$ of BSA were injected in the hindpaw using 30 gauge needle connected to a Hamilton syringe. The injected volume was $10 \mu \mathrm{l}$ for NAGly, morphine, and BSA solution and $20 \mu \mathrm{l}$ for the NAGABA-OH solution. Controls were performed using the same injected volume with the solvent alone, which induced no significant effect. All experiments were conducted following the Guidelines of the Committee for Research and Ethical Issue (Zimmermann, 1983) and in full compliance with institutional regulation on animal care and use.

Chemical reagents. Lipids were obtained from Cayman Chemical and other compounds from Sigma. In a subset of experiments, we used NAGly from Alexis Biochemicals and from Biomol and we found similar effects of NAGly on Cav3.2 ( $\sim 85 \%$ inhibition at $3 \mu \mathrm{M}, n=10-11)$. Lipids were dissolved in ethanol at a concentration of $10-100 \mathrm{~mm}$. Stock solutions were briefly sonicated, aliquoted, sealed under argon, and kept at $-80^{\circ} \mathrm{C}$. These aliquots were dissolved daily in the extracellular solution. Control experiments were performed using the solvent alone.

\section{Results}

$N$-Arachidonoyl amino acids inhibit Cav3.2 current

We first investigated whether NAGly modulates T-channels expressed in tsA-201 cells (Fig. 1). We found that Cav3.2 currents were strongly inhibited by $3 \mu \mathrm{M}$ NAGly (90\% inhibition) (Fig. $1 A)$. This effect occurred in the minute range and was relieved (by $84 \pm 3 \%, n=26$ ) with a perfusion containing bovine serum albumin (BSA, $3 \mathrm{mg} / \mathrm{ml}$ ) (Fig. 1A,B). NAGly also inhibited Cav3.1 and Cav3.3 currents $(\sim 75 \%$ and $\sim 70 \%$ inhibition at 3 $\mu \mathrm{M}$, respectively) (see Fig. $4 F$ and supplemental Fig. 1, available at www.jneurosci.org as supplemental material). As observed with Cav3.2, the NAGly effects on Cav3.1 and Cav3.3 currents occurred in the minute range and were relieved with BSA perfusion (supplemental Fig. $1 A-D$, available at www.jneurosci.org as supplemental material) (washout was $94 \pm 4 \%, n=17$ for Cav3.1 and $79 \pm 7 \%, n=11$ for Cav3.3). Similar findings were obtained on a Cav3.2 mutant, Cav3.2(H191Q), insensitive to trace metals (such as zinc) (Nelson et al., 2007a), which was inhibited by $3 \mu \mathrm{M}$ NAGly ( $88 \pm 2 \%$ inhibition, $n=6$ ) with a similar recovery after BSA perfusion ( $86 \pm 7 \%$ recovery, $n=6$ ) (supplemental Fig. $1 E, F$, available at www.jneurosci.org as supplemental material), suggesting that in our experiments BSA effects did not involved trace metal chelation. We also found that a similar recovery of Cav3.2 currents after NAGly inhibition was obtained using $1 \mathrm{~mm}$ 
$\beta$-cyclodextrin (recovery was $85 \pm 5 \%, n=$ 6) (see supplemental Fig. $1 G, H$, available at www.jneurosci.org as supplemental material). Because NAGly is a substrate for FAAH (Huang et al., 2001) leading to arachidonic acid formation, which also inhibited Cav3 currents (Chemin et al., 2007a), we investigated the effects of FAAH inhibitors. We found that treatment with $100 \mu \mathrm{M}$ phenylmethanesulfonyl fluoride (PMSF, Deutsch and Chin, 1993) or with $1 \mu \mathrm{M}$ URB597 (Kathuria et al., 2003) did not inhibit the NAGly effects on Cav3.2 (inhibition at $3 \mu \mathrm{M}$ was $86 \pm 1 \%, n=7$, and was $88 \pm 2 \%, n=5$, in the presence of PMSF and URB597, respectively) (see supplemental Fig. 2, available at www.jneurosci.org as supplemental material).

We next investigated whether Cav3.2 currents were inhibited by other $\mathrm{N}$-arachidonoyl amino acids containing either a serine (NASer), an alanine (NAAla), a $\gamma$-aminobutyric acid (NAGABA), or a 3-OH$\gamma$-aminobutyric acid (NAGABA-OH) group (see schematic structures in Fig. 1C). We found that Cav3.2 currents were strongly inhibited by all these lipoamino acids ( 73-98\% inhibition) (Fig. $1 D$ ) as well as by NAEA ( $\sim 80 \%$ inhibition) (Fig. $1 D)$ and $\mathrm{N}$-arachidonoyl taurine (NATau; $\sim 90 \%$ inhibition) (Fig. $1 D$ ), and these effects were relieved by a BSA perfusion (data not shown). The NAGly-induced inhibition of Cav3 currents was dose dependent (Fig. 1E) with half-maximal effects $\left(\mathrm{EC}_{50}\right)$ at $600 \pm 40 \mathrm{~nm}$ for Cav3.2 $(n=9), 1.3 \pm 0.1 \mu \mathrm{M}$ for Cav3.1 $(n=12)$ and $1.6 \pm 0.2 \mu \mathrm{M}$ for $\operatorname{Cav} 3.3(n=9)$. Furthermore, these experiments revealed that NAGABA-OH was a potent T-channel blocker (Fig. $1 D-F$ ) with an $\mathrm{EC}_{50}$ of $210 \pm 12 \mathrm{~nm}$ for Cav3.2 currents, $800 \pm 60$ $\mathrm{nM}$ for Cav3.1, and $1.3 \pm 0.1 \mu \mathrm{M}$ for Cav3.3.

\section{A shift in the steady-state inactivation properties explains the current inhibition}

We next examined whether current inhibition involves modifications in macroscopic properties of Cav3 currents (Fig. 2). First, we observed that Cav3.2 currents were inhibited at all potentials (Fig. 2A) with a similar inhibition of both inward and outward currents (Fig. $2 B$ ), suggesting that a screen charge effect is unlikely. In addition, the effects of NAGABA-OH were independent of the stimulation frequency (Fig. 2C), further discarding an open channel block mechanism. Analysis of the current-voltage curves revealed a $\sim 5 \mathrm{mV}$ shift in half activation (Fig. $2 \mathrm{~A}$ ) from $-45.3 \pm 0.1 \mathrm{mV}$ in control condition to $-50.1 \pm 0.2 \mathrm{mV}$ during $3 \mu \mathrm{M}$ application $(p<0.01)$. NAGABA-OH also increased the slope of activation from $5.5 \pm 0.1$ to $7.4 \pm 0.1 \mathrm{mV} / e$-fold during $3 \mu \mathrm{M}$ application $(p<0.01)$. However, this shift could not explain the observed inhibition and we further investigated the effects of NAGABA-OH on the steady-state inactivation proper-
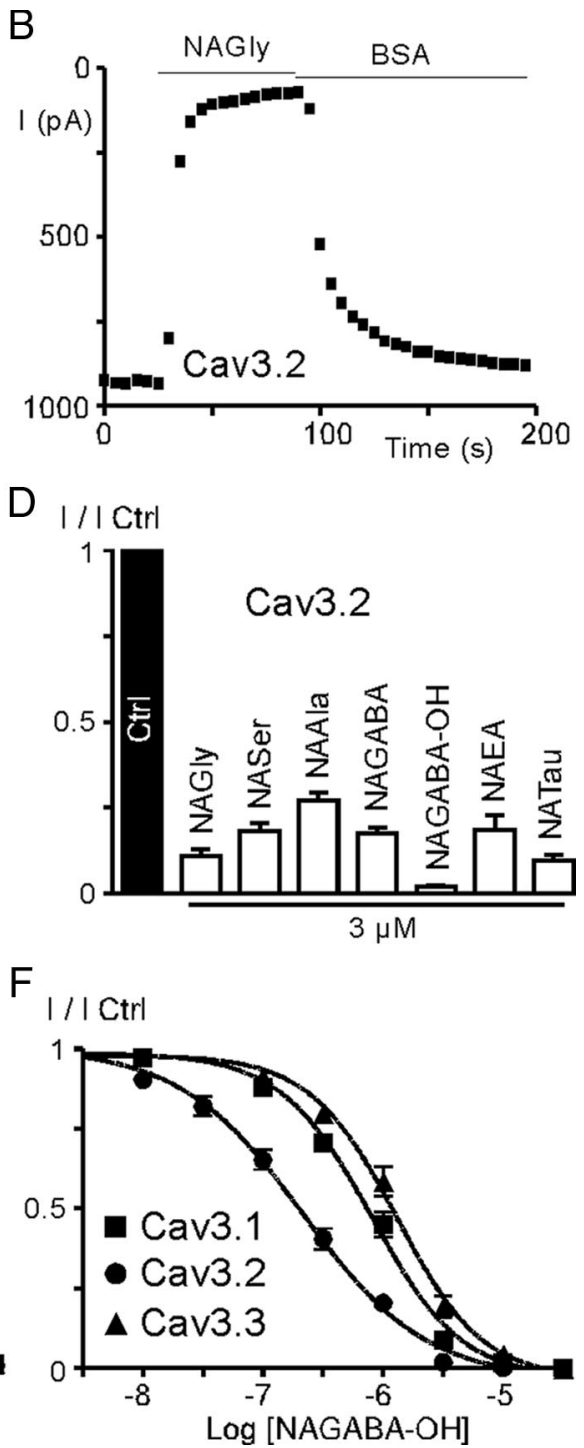

Figure 1. $\quad$ N-Arachidonoyl amino acids inhibit Cav3 currents. $\boldsymbol{A}$, Whole-cell calcium currents recorded from a tsA-201 cell , Time course of the decrease in Cav3.2 current amplitude during NAGly application and subsequent washout with the BSA (N) (NATau). D , Summary of the effects of $N$-arachidonoyl amino acids and of NATau and NAEA ( $n=14-27$ ). $\boldsymbol{E}, \boldsymbol{F}$, Dose dependence of Cav3 current inhibition by NAGly $(\boldsymbol{E}, n=5-20$ per points) and NAGABA-OH $(\boldsymbol{F}, n=3-18$ per points). Cav3 current inhibition was fitted with the sigmoidal Hill equation.

ties Cav3.2 currents (Fig. 2D,E). We found that NAGABA-OH induced an important dose-dependent hyperpolarized shift $(\sim 20 \mathrm{mV})$ in the steady-state inactivation of Cav3.2 currents (Fig. $2 D, E)(p<0.01)$. The half inactivation values $\left(V_{0.5}\right)$ were $-71.9 \pm 0.9 \mathrm{mV}$ in control condition, $-81.1 \pm 0.8 \mathrm{mV}$ during 1 $\mu \mathrm{M}$ NAGABA-OH application and $-93.1 \pm 1.7 \mathrm{mV}$ during $3 \mu \mathrm{M}$ NAGABA-OH application (Fig. 2E). This result indicates that NAGABA-OH has pronounced effects at physiological holding potentials (HPs, $\sim-85 /-65 \mathrm{mV}$ ) for which T-channels are partially inactivated. Furthermore, this latter result suggests that NAGABA-OH could act specifically on inactivated T-channels. To directly test this hypothesis, NAGABA-OH was applied to cells maintained at a $\mathrm{HP}$ of $-110 \mathrm{mV}$, for which T-channels are mainly in the closed state (Fig. $2 F$ ). In these conditions, NAGABA-OH did not produce inhibition of Cav3.2 currents 
A

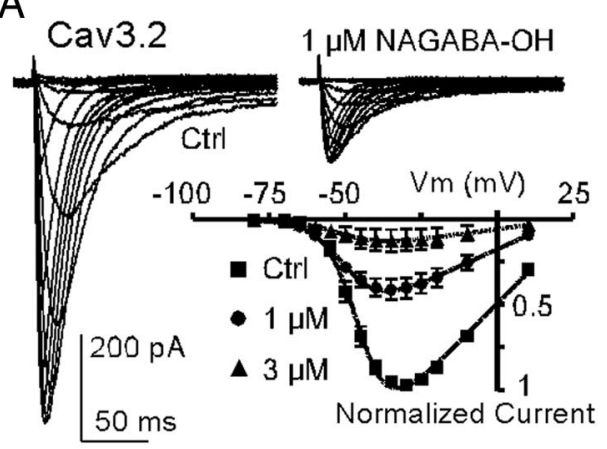

$\mathrm{B}$

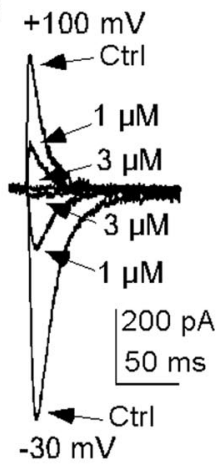

C

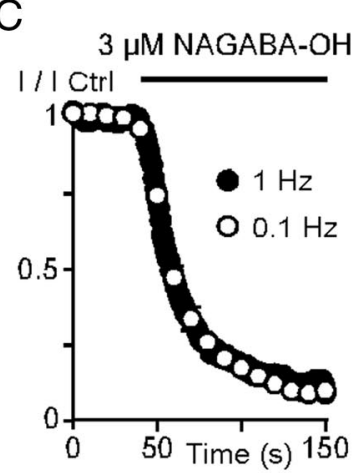

E

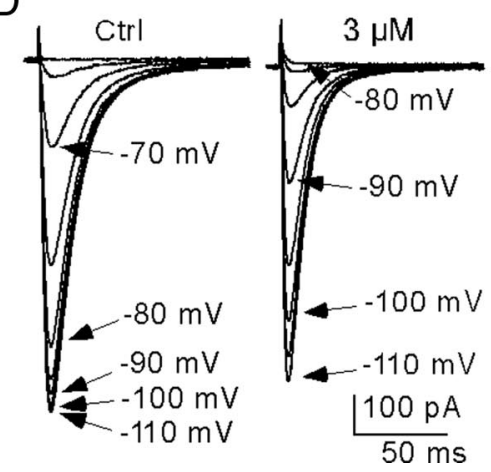

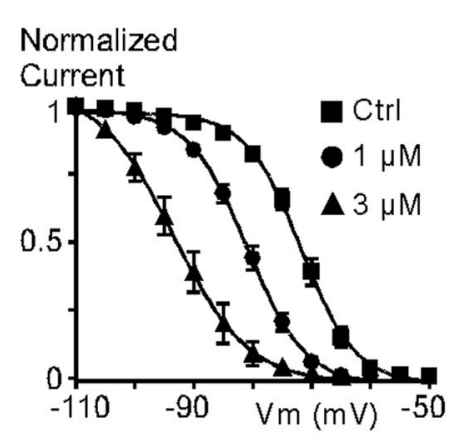

$\mathrm{F}$

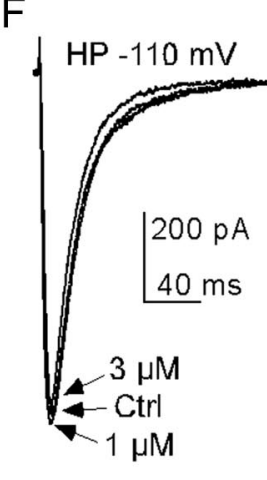

Figure 2. NAGABA-OH induces a strong shift in steady-state inactivation properties of Cav3.2 channels. $A$, Representative families of Cav3.2 currents recorded in the absence and presence of $1 \mu \mathrm{m}$ NAGABA-OH. Effects of NAGABA-OH on current-voltage ( $I-\eta$ curves of Cav3.2 currents is presented as an inset $(n=5-9)$. The current traces were elicited by a series of step depolarizations ranging from -80 to $+10 \mathrm{mV}$ (200 ms duration) from $-80 \mathrm{mV}$. B, Similar inhibition of inward and outward Cav3.2 currents by NAGABA-OH ( $n=5-11)$. In these experiments capacitive and background currents were subtracted by a $-\mathrm{P} / 8$ protocols. C, Cav3.2 current inhibition by NAGABA-OH is not frequency dependent $(n=13-14)$. Currents were elicited by a depolarization at $-30 \mathrm{mV}$ ( $200 \mathrm{~ms}$ duration) applied from $-75 \mathrm{mV}$ at a frequency of 1 or $0.1 \mathrm{~Hz}$. D. Cav3.2 currents elicited at $-30 \mathrm{mV}$ from HPs ranged from $-110 \mathrm{mV}$ to $-60 \mathrm{mV}$ ( $10 \mathrm{~s}$ duration, $5 \mathrm{mV}$ increments) in the absence and presence of $3 \mu \mathrm{M} \mathrm{NAGABA-OH}$. $\boldsymbol{E}$, Steady-state inactivation curves obtained from experiments illustrated in (D). Data were fitted with the Boltzmann equation $(n=10-15)$. $\boldsymbol{F}$, No significant effect of NAGABA-OH when applied at a HP of $-110 \mathrm{mV}$.

A

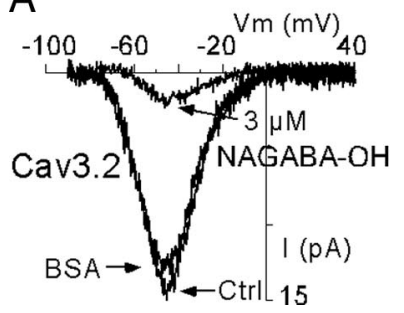

B

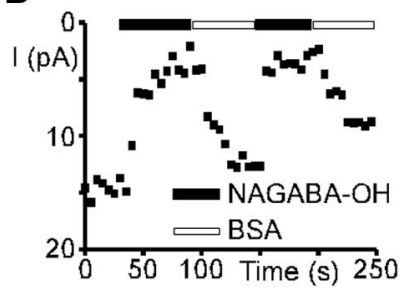

C

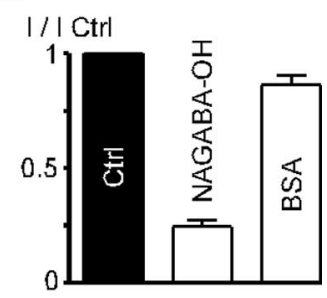

Figure 3. Inhibition of Cav3.2 currents by NAGABA-OH in cell-free outside-out patches. $\boldsymbol{A}$, Effects of $3 \mu \mathrm{m}$ NAGABA-OH on Cav3.2 currents recorded in an outside-out patch. Currents were elicited by a voltage ramp of $100 \mathrm{~ms}$ duration from $-90 \mathrm{mV}$ to $+40 \mathrm{mV}$ applied every $5 \mathrm{~s}$ from $-90 \mathrm{mV}$. $\boldsymbol{B}$, Time course of the decrease in Cav3.2 current amplitude during NAGABA-OH application and subsequent washout with the BSA solution. C, Summary of the effects of NAGABA-OH on Cav3.2 currents obtained in outside-out patch configuration ( $n=10-15)$.

$(n=10)$ (Fig. $2 F)$. Together, our data suggest that NAGABA-OH inhibits Cav3.2 currents by stabilizing the channels in the inactivated state, leading to a strong shift in the inactivation curve and therefore to an inhibition of the current at physiological HPs.

\section{Cav3.2 current inhibition persists in cell-free}

outside-out patches

To determine whether Cav3.2 current inhibition involves lipid metabolism, GPCR activation or protein kinase pathways, we performed cell-free outside-out patch recordings using an "intracellular" medium lacking both GTP and ATP (Fig. 3). In this configuration, Cav3.2 currents were inhibited by the application of 3 $\mu \mathrm{M}$ NAGABA-OH (Fig. $3 A$ ) with a similar time course to that ob-

served in whole-cell experiments (Fig. 3B), and these effects were relieved by a BSA perfusion. On average we found that the Cav3.2 currents were inhibited by $76 \pm 3 \%$ when 3 $\mu \mathrm{M}$ NAGABA-OH was applied in outsideout patches (Fig. 3 C), indicating that Cav3.2 inhibition occurs in a membrane-delimited manner.

\section{Effects of NAGly and NAGABA-OH on}

HVA calcium channels, sodium

channels, and anandamide-sensitive TRPV1 and TASK1 channels

We next investigated the effects of $\mathrm{N}$-arachidonoyl amino acids on Cav1.2 and Cav2.2 HVA calcium channels (Fig. 4). We found that both Cav1.2 and Cav2.2 currents were weakly affected by $3 \mu \mathrm{M}$ NAGly and $3 \mu \mathrm{M}$ NAGABA-OH (Fig. $4 A, B$ ). On average both compounds produced $\sim 5 \%$ inhibition of Cav1.2 currents and $\sim 25 \%$ inhibition of Cav2.2 currents (Fig. $4 F, G$ ). Furthermore, $10 \mu \mathrm{M}$ NaGly and $10 \mu \mathrm{M}$ NAGABA-OH did not further inhibit (nor activate, see below) Cav1.2 and Cav2.2 currents $(n>15)$. Because these results were obtained for a HP of $-75 \mathrm{mV}$, the selectivity of NAGly and NAGABA-OH could be explained by the steady-state inactivation properties of HVA currents compared with those of Cav3 currents (which were inactivated by $\sim 35 \%$ at this HP) (Fig. 2 E). We then performed a subset of experiments at more depolarized HPs, allowing the inactiva- 

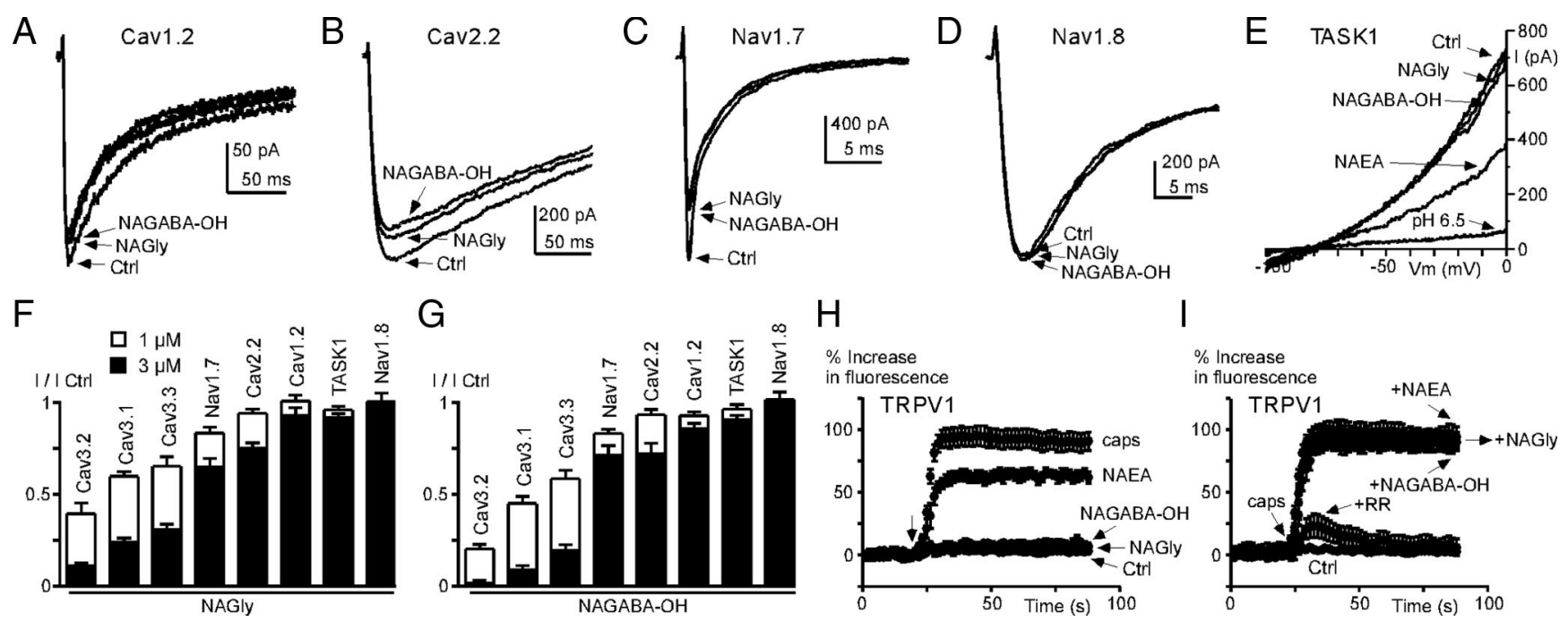

Figure 4. Effects of NAGly and NAGABA-OH on recombinant Cav1.2, Cav2.2, Nav1.7, Nav1.8, TASK1, and TRPV1 channels. A-C, Whole-cell currents recorded from tsA-201 cells expressing Cav1.2 channels (A), Cav2.2 (B), and Nav1.7 ( $)$ in the absence and presence of $3 \mu \mathrm{m} \mathrm{NAGly} \mathrm{and} 3 \mu \mathrm{m}$ NAGABA-0H. Currents were elicited by a depolarization at $0 \mathrm{mV}$ ( $200 \mathrm{~ms}$ duration for Cav1.2 and Cav2.2 or $20 \mathrm{~ms}$ for Nav1.7) applied every $5 \mathrm{~s}$ from $-75 \mathrm{mV}$. D, Effects of $3 \mu \mathrm{m}$ NAGly and $3 \mu \mathrm{m}$ NAGABA-OH on whole-cell currents recorded from a F11 cell expressing Nav1.8. Currents were elicited in the presence of $0.5 \mu \mathrm{m}$ TTX by a depolarization at $0 \mathrm{mV}$ ( $30 \mathrm{~ms}$ ) applied every $5 \mathrm{~s}$ from $-65 \mathrm{mV}$. E, Inhibition of TASK1 currents by $3 \mu \mathrm{m}$ NAEA but not by $3 \mu \mathrm{m}$ NAGly and NAGABA-OH. TASK 1 currents are inhibited by a mild extracellular acidification, pH 6.5. Currents were elicited by voltage ramps of $1 \mathrm{~s}$ duration from -100 to $0 \mathrm{mV}$ applied every $5 \mathrm{~s}$ from $-80 \mathrm{mV}$. $F, G$, Summary of the effects of 1-3 $\mu \mathrm{m} \mathrm{NAGly} \mathrm{(F,} n=6-28)$ and NAGABA-OH (G, $n=6-19)$. H, Activation of TRPV1 by $10 \mu \mathrm{m}$ NAEA but not by $10 \mu \mathrm{m}$ NAGly and $10 \mu \mathrm{m} \mathrm{NAGABA-OH}$. Intracellular calcium measurements were performed using Flu04-AM and drugs were applied at the time indicated by an arrow. All measurements were performed on four independent 96-well plates and were normalized to the response obtained with $1 \mu \mathrm{m}$ capsaicin (caps.) $\boldsymbol{I}, 10 \mu \mathrm{m}$ ruthenium red (RR) but not $10 \mu \mathrm{m}$ NAEA, NAGly, and NAGABA-0H inhibits TRPV1 activation by $1 \mu \mathrm{m}$ capsaicin. Similar experiments as in $\boldsymbol{H}$ except that Ctrl indicates the capsaicin response obtained in untransfected cells (for clarity errors bars were omitted).

tion of Cav1.2 and Cav2.2. At a HP of $-40 \mathrm{mV}$, for which Cav1.2 currents were inactivated by $\sim 65 \%(63 \pm 2 \%, n=15), 3 \mu \mathrm{M}$ NAGly and NAGABA-OH produced $\sim 5-10 \%$ inhibition of Cav1.2 currents ( $6 \pm 7 \%$ inhibition, $n=8$, and $7 \pm 3 \%$ inhibition, $n=7$, respectively). Similarly, for a HP of $-65 \mathrm{mV}$, Cav2.2 currents were inactivated by $\sim 65 \%(66 \pm 2 \%, n=16)$, whereas $3 \mu \mathrm{M}$ NAGly and NAGABA-OH produced a mild inhibition of Cav2. 2 currents ( $26 \pm 4 \%$ inhibition, $n=7$, and $31 \pm 9 \%$ inhibition, $n=9$, respectively). Therefore, in contrast with T-channel inhibition, the effects of NAGly and NAGABA-OH on HVA calcium channels were not dependent of the HP. We also provide evidence that Nav1.7 and Nav1.8 sodium channels, which have an important role in pain perception (Wood et al., 2004), were mildly inhibited by NAGly and NAGABA-OH (Fig. 4C,D). We found that Nav1.7 currents were inhibited $\sim 15 \%$ by $1 \mu \mathrm{M}$ NAGly and NAGABA-OH and $\sim 30 \%$ at a concentration of $3 \mu \mathrm{M}$ (Fig. $4 F, G$ ). In these experiments the $\mathrm{HP}$ was $-75 \mathrm{mV}$ allowing the inactivation of Nav1.7 by $\sim 55 \%$ $(53 \pm 2 \%, n=14)$. In the same way at $\mathrm{HP}-65 \mathrm{mV}$, Nav1.8 currents were inactivated $\sim 35 \%(34 \pm 4 \%, n=15)$, whereas $3 \mu \mathrm{M}$ NAGly and NAGABA-OH produced no significant inhibition (Fig. $4 F, G$ ). We also found that the TASK1 potassium current, which was inhibited by $3 \mu \mathrm{M}$ NAEA ( $59 \pm 2 \%$ inhibition, $n=9$ ) (Fig. $4 E$ ), was insensitive to $3 \mu \mathrm{M}$ NaGly and $3 \mu \mathrm{M} \mathrm{NaGABA}-\mathrm{OH}$ (Fig. $4 F, G$ ). In addition, $10 \mu \mathrm{M} \mathrm{NaGly}$ and $10 \mu \mathrm{M}$ NAGABA-OH neither activated nor inhibited the TRPV1 current, which was activated by $10 \mu \mathrm{M}$ NAEA and inhibited by $10 \mu \mathrm{M}$ ruthenium red (Fig. $4 H, I$ ).

\section{NAGly and NAGABA-OH produce thermal analgesia via Cav3.2 inhibition}

We conducted electrophysiological recordings from dissociated DRG neurons to determine whether NAGly regulation also occurs with native T-channels. NAGly application resulted in a markedly reduced whole-cell T-current activity in DRG neurons (Fig. 5A), which was relieved by a BSA perfusion. In line with the results obtained in transient expression systems, we found that
NAGly had weak effects on the HVA calcium currents (Fig. 5B) as well as on both total sodium currents (Fig. 5C) and TTX-resistant sodium currents (Fig. 5D). On average, we found that $3 \mu \mathrm{M}$ NAGly produced an $79 \pm 2 \%$ inhibition of T-currents in DRG neurons, whereas HVA currents were decreased by $24 \pm 2 \%$, total sodium currents by $4 \pm 2 \%$, and TTX-resistant sodium currents by $13 \pm 2 \%$ (Fig. $5 E$ ). Because NAGly produces analgesia in several models independently of $\mathrm{CB}$ receptors and TRPV1 (Huang et al., 2001; Burstein et al., 2002; Bradshaw and Walker, 2005; Burstein, 2008; Succar et al., 2007; Vuong et al., 2008), we tested whether the NAGly-induced inhibition of T-currents results in analgesia. For this purpose, hindpaw PWL to a noxious thermal stimulus $\left(46^{\circ} \mathrm{C}\right)$ was measured in both wild-type (WT) and Cav3.2 KO mice. NAGly increased PWL in WT mice, with strong effects $10 \mathrm{~min}$ after the injection [PWL was $11.1 \pm 0.5 \mathrm{~s}$ in vehicle-treated group and $19.3 \pm 1.6 \mathrm{~s}$ in NAGly-treated group $(p<0.01)$ (Fig. 5F)]. In agreement with our hypothesis, NAGly displayed no significant analgesic effect in Cav3.2 KO mice (Fig. $5 G)$. Similar findings were obtained with NAGABA-OH, which induced a potent PWL increase in WT $(p<0.01)$ but not in Cav3.2 KO mice (Fig. 5I,J). Importantly, NAGABA-OH injection did not induce significant PWL increase in contralateral (uninjected) hindpaw (Fig. 5I), indicating that NAGABA-OH acted locally in skin nociceptors. In contrast to lipoamino acids, morphine induced a significant PWL increase in both WT and Cav3.2 $\mathrm{KO}$ mice $(p<0.01)$ (Fig. $5 H-K)$. Because, in electrophysiological experiments we used BSA to remove T-current inhibition by lipoamino acids, we investigated the effect of a BSA solution when injected in the hindpaw. In opposition with the effects of lipoamino acids, we found that BSA induced a thermal hyperalgesia in WT mice $(p<0.01)$ (Fig. $5 H)$. Importantly, no hyperalgesic effect of BSA was observed in Cav3.2 KO mice (Fig. $5 \mathrm{~K}$ ). Overall, our data indicate that Cav3.2 inhibition at peripheral sites is an important physiological mechanism underlying the analgesic effects of lipoamino acids. 


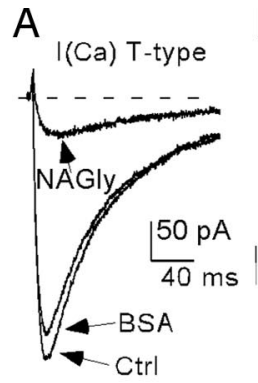

F

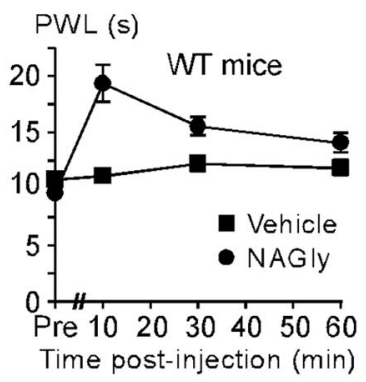

I

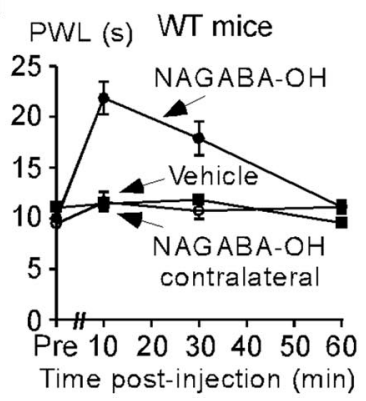

B

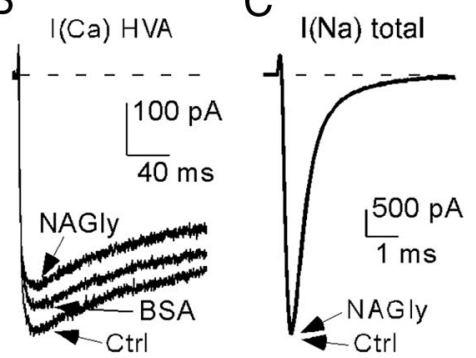

G

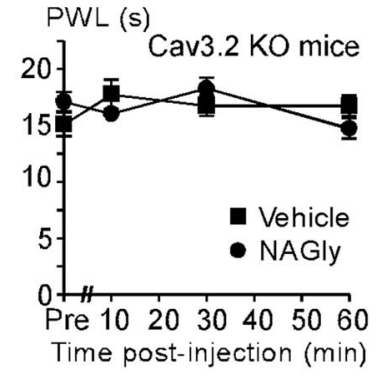

$\mathrm{J}$

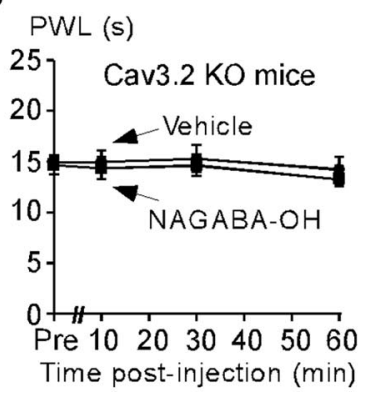

E

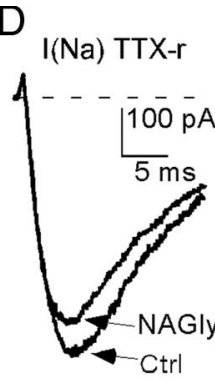

$\mathrm{H}$

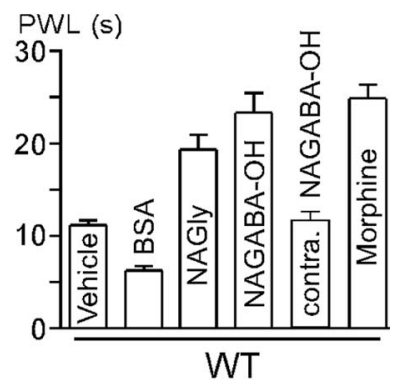

$\mathrm{K}$

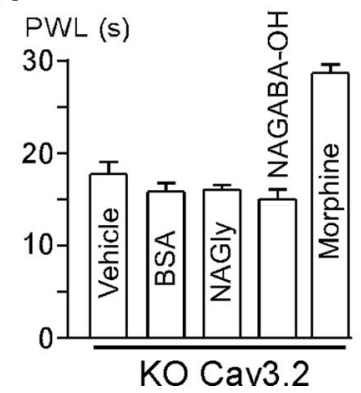

Figure 5. Inhibition of Cav3.2 in sensory neurons underlies NAGly-induced analgesia. $\boldsymbol{A}, \boldsymbol{B}$, Calcium currents recorded (in the absence of sodium) from DRG neurons in the absence (Ctrl) and presence of $3 \mu \mathrm{m}$ NAGly and after washout with a solution containing $3 \mathrm{mg} / \mathrm{ml}$ BSA. Currents were elicited by a depolarization ( $200 \mathrm{~ms})$ at $-30 \mathrm{mV}(\boldsymbol{A}, \mathrm{T}$-type) or at $0 \mathrm{mV}$ ( $\boldsymbol{B}, \mathrm{HVA})$ applied every $5 \mathrm{~s}$ from $-75 \mathrm{mV}$. C, $\boldsymbol{D}$, Effects of NAGly on sodium currents in DRG neurons. Sodium currents were recorded in the presence of $10 \mu \mathrm{M} \mathrm{La}{ }^{3+}$ (a calcium channel blocker) with $[\boldsymbol{D}, /(\mathrm{Na}) \mathrm{TTX}-\mathrm{r}]$ or without [C, /(Na) total] $0.5 \mu \mathrm{M}$ TTX. Currents were elicited by a depolarization at $0 \mathrm{mV}$ ( $20 \mathrm{~ms}$ duration) applied every $5 \mathrm{~s}$ from $-70 \mathrm{mV}$ (C) or $-50 \mathrm{mV}$ (D). E, Summary of the effects of NAGly on calcium and sodium currents in DRG neurons ( $n=10-12)$. To limit the contamination of T-currents by HVA currents, and vice versa, HVA currents were measured as the remaining current after $150 \mathrm{ms,}$, whereas T-currents were measured as the difference between the peak current and the remaining current after $150 \mathrm{~ms} . \boldsymbol{F}, \mathbf{G}$, Effects of vehicle and NAGly solution on thermal pain $\left(46^{\circ} \mathrm{C}\right)$ when injected in the hindpaw in WT $(\boldsymbol{F})$ and Cav3.2 K0 mice (G). Results are expressed as the PWL as a function of the time after injection. The "Pre" values represent the values obtained before injection. $\boldsymbol{H}$, Summary of the data obtained in WT mice 10 min after injection of vehicle, BSA, NAGly, NAGABA-OH, and morphine ( $n=8-10$ mice per bars). Effect of NAGABA-OH on PWL in contralateral (contra). is also reported in WT mice $(n=9)$. $I, J$, Effects of vehicle and NAGABA-OH solution on thermal pain $\left(46^{\circ} \mathrm{C}\right)$ when injected in the hindpaw in WT $(I)$ and $\mathrm{Cav3} .2 \mathrm{KO}$ mice $(J)$. Effect of NAGABA-OH on PWL in contralateral is also reported for WT mice as indicated (I). $\boldsymbol{K}$, Summary of the data obtained in Cav3.2 $\mathrm{KO}$ mice 10 min after injection of vehicle, BSA, NAGly, NAGABA-OH, and morphine ( $n=8-10$ mice per bars).

\section{Discussion}

In this study, we demonstrate that NAGly strongly inhibits recombinant and native T-current in sensory neurons. This effect is not restricted to NAGly, and several mammalian lipoamino acids are potent inhibitors. Inhibition persists in cell-free patches, occurs at all potentials, and involves a large hyperpolarized shift in the steady-state inactivation of T-currents. We found that lipoamino acids have weak effects on HVA calcium channels and sodium channels as well as on TRPV1 and TASK1 channels [both being anandamide sensitive (Zygmunt et al., 1999; Julius and Basbaum, 2001; Maingret et al., 2001; van der Stelt and Di Marzo, 2005)]. In line herewith, lipoamino acids evoked a thermal analgesia in WT but not in Cav3.2 KO mice.

NAGly and NAGABA are potent analgesics despite their inactivity at CB1 and TRPV1 receptors (Huang et al., 2001; Bradshaw and Walker, 2005; Burstein, 2008; Succar et al., 2007; Vuong et al., 2008). NAGly is widely distributed among mammalian tissues and particularly in the pain neuraxis, including the skin, the spinal cord, and the brain (Huang et al., 2001). NAGly causes anal- gesia in the hot plate test and suppresses inflammation-induced pain (Huang et al., 2001; Burstein et al., 2002; Bradshaw and Walker, 2005; Burstein, 2008; Succar et al., 2007; Vuong et al., 2008). Here, we provide evidence indicating that the lipoamino acid analgesic effects largely result from $\mathrm{T}$-channel inhibition. We found that NAGly strongly inhibits recombinant Cav3 channels, especially Cav3.2 with an $\mathrm{EC}_{50}$ of $\sim 600 \mathrm{~nm}$. Similarly, other lipoamino acids NASer, NAAla, and NAGABA are potent T-channel inhibitors and particularly NAGABA-OH with an $\mathrm{EC}_{50}$ of $\sim 200 \mathrm{nM}$ for Cav3.2. It should be noted that NAGly, NAGABA, and NASer were identified in mammalian tissues (Huang et al., 2001; Bradshaw and Walker, 2005; Milman et al., 2006), but the presence of NAGABA-OH needs further investigations. Interestingly, similar T-channel inhibition was obtained with NATau, which has a sulfonic instead a carboxylic group and is also a TRPV1 activator (Saghatelian et al., 2006). We also report that the inhibition persists in cell-free outside-out patch using an intracellular medium lacking GTP and ATP, indicating that lipoamino acids likely act directly on Cav3 current. Overall, 
lipoamino acids appear to be the most active endogenous ligand family acting on T-channels.

We describe that lipoamino acids have no effect on TRPV1, TASK1, Nav1.7, and Nav1.8 channels as well as on Cav1.2 and Cav2.2 calcium channels. It was showed recently that NAGly and NASer produce an increase of $\mathrm{N}$-type currents (Cav2.2 related) in sympathetic ganglion neurons (Guo et al., 2008). We did not observe this effect on HVA currents recorded from dissociated DRG neurons, which express mainly N-type currents (Beedle et al., 2004), and this regulation could be specific of sympathetic neurons. Interestingly, using recombinant Cav2.2 we found in $\sim 30 \%$ of the cells a transient current increase $(\sim 20 \%$ on average), which was followed by a small current decrease compared with control values.

Alternative mechanisms were proposed to explain the biological activity of NAGly. NAGly is subject to cyclooxygenase and lipooxygenase metabolism, producing metabolites with unknown functions (Prusakiewicz et al., 2007). However, these metabolites are probably not involved in the T-channel inhibition since similar inhibition was obtained in cell-free outside-out patches. The NAGly effects could also involve the inhibition of FAAH leading to an increase in NAEA levels (Huang et al., 2001; Burstein et al., 2002). However, NAGly analgesic effects persist in the presence of CB receptor antagonists suggesting that NAGly mediates analgesia independently of NAEA levels (Succar et al., 2007; Vuong et al., 2008). Accordingly, we found that Cav3.2 inhibition persisted after incubation with PMSF or URB597, both being potent FAAH inhibitors (Deutsch and Chin, 1993; Kathuria et al., 2003). NAGly also inhibits the GLYT2a glycine transporter with an $\mathrm{EC}_{50}$ of $\sim 5 \mu \mathrm{M}$ (Wiles et al., 2006). However, NAGly effects are complex leading to both potentiating and inhibitory effects (Yang et al., 2008), similar to those observed on HVA calcium channels. Finally, NAGly was initially described as a potential ligand for orphan GPCRs GPR18 and GPR92 (Kohno et al., 2006; Oh et al., 2008) but these results were not confirmed in recent studies (Williams et al., 2009; Yin et al., 2009) and need further investigation.

We demonstrated that NAGly strongly inhibits native T-currents in DRG neurons, which are mainly supported by Cav3.2 channels. Recent studies demonstrate a high density of Cav3.2 currents in a subpopulation of DRG nociceptors (termed "T-rich" or "c2type"), which express mechanosensitive currents and TRPV1 currents (Nelson et al., 2005; Coste et al., 2007). In these neurons, Cav3.2 currents promote neuronal activities by lowering the action potential threshold (Nelson et al., 2005, 2007a). Accordingly, it was demonstrated that agents that enhance T-currents (as L-cysteine) induce a thermal and mechanical sensitization, whereas inhibitors produce an analgesia (Todorovic et al., 2001; Nelson et al., 2007a). In line herewith, we demonstrate that both NAGly and NAGABA-OH evoked a thermal analgesia in WT but not in Cav3.2 $\mathrm{KO}$ mice. In agreement with previous studies (Bourinet et al., 2005; Choi et al., 2007), we observed that Cav3.2 KO mice display a basal thermal analgesia. Despite their constitutive analgesia, we provide evidence that a strong pharmacological analgesia can be obtained in Cav3.2 KO mice, as assessed with morphine. However, it should be noted that morphine is a very potent analgesic and this would explain its effect in Cav3.2 KO mice. Interestingly the level of analgesia obtained with NAGABA-OH was equivalent to that induced with the same dose of morphine. We also try to investigate whether endogenous lipoamino acids produced a tonic T-current inhibition "in vivo" and its potential implication in pain. Since no adequate pharmacological tool to manipulate the "in vivo" lipoamino acid levels is described, we used an alternative approach. We provide evidence that BSA, which removes T-current inhibition by lipoamino acids in our electrophysiological experiments, induced a thermal hyperalgesia in WT mice. It should be noted that BSA effects could involve the removal of other endogenous T-channel ligands, including zinc (Nelson et al., 2007a) or other lipids (Chemin et al., 2007a; Ross et al., 2009), as well as the removal of endogenous ligands acting on other targets [as anandamide on TRPV1 (De Petrocellis et al., 2001)]. Importantly the BSA effects were absent in the Cav3.2 KO mice, suggesting a T-channeldependent mechanism. These findings suggest that a reduction in the tonic inhibition of Cav3.2 currents by endogenous ligands induces hyperactivation of afferent pain fibers.

Our data reveal that the lipoamino acid-induced inhibition of Cav3.2 current is dependent of the channel inactivation state. The block is negligible for negative HPs at which the Cav3.2 channels are mostly in the closed state. Also, the block involves a large shift $(\sim 20 \mathrm{mV})$ in the Cav3.2 steady-state inactivation curve. These findings indicate that lipoamino acids produced current inhibition by stabilizing the channels in the inactivated state, leading to a shift in the inactivation properties and to current inhibition at physiological membrane potentials. Binding to the inactivated channels is an important feature of the lipoamino acid-induced inhibition of Cav3.2 currents since it could confer tissue selectivity. For instance, the dihydropyridines that preferentially inhibit inactivated L-type channels are anti-hypertensive drugs by acting on vascular tissues while having little effect on the heart (Triggle, 1992). In this context, it should be noted that NASer, which has recently been isolated from brain, induced vasodilatation in rat mesenteric arteries and abdominal aorta (Milman et al., 2006). Considering that $\mathrm{T}$-currents are expressed in several vascular tissues and that Cav3.2 KO mice present an impaired vasorelaxation (Chen et al., 2003), the modulation described in this study could account for vasodilatory properties of lipoamino acids.

While our study highlights Cav3.2 as an important target for lipoamino acids, we found that Cav3.1 and Cav3.3 were also inhibited $\left(\mathrm{EC}_{50} \sim 1 \mu \mathrm{M}\right)$. Whereas the physiological role of Cav3.3 is still unknown, KO mouse studies indicated that thalamic Cav3.1 is implicated in slow-wave sleep (Lee et al., 2004) and absence epilepsy (Kim et al., 2001). Furthermore, it was demonstrated that Cav3.2 is also implicated in epileptogenesis and that Cav3.2 KO mice present resistance to spontaneous seizures in a hippocampal epilepsy model (Becker et al., 2008). Since lipoamino acids NAGly and NAGABA were found in high level in the hippocampus and the thalamus (Bradshaw et al., 2006), they could be relevant to this neurological disorder by acting on both Cav3.1 and Cav3.2. Overall, lipoamino acids could modulate many physiological and pathophysiological events via the inhibition of the three T-channels. Future studies will be necessary to confirm these issues, as demonstrated here in pain perception.

In summary, we provide evidence for a new regulation of T-channels occurring via an endogenous ligand family, most members of which are present at sites where T-channels are expressed and display major functions. The potent inhibition of these channels by lipoamino acids suggests that this modulation is highly relevant to neuronal physiology.

\section{References}

Becker AJ, Pitsch J, Sochivko D, Opitz T, Staniek M, Chen CC, Campbell KP, Schoch S, Yaari Y, Beck H (2008) Transcriptional upregulation of Cav3.2 mediates epileptogenesis in the pilocarpine model of epilepsy. J Neurosci 28:13341-13353.

Beedle AM, McRory JE, Poirot O, Doering CJ, Altier C, Barrere C, Hamid J, Nargeot J, Bourinet E, Zamponi GW (2004) Agonist-independent mod- 
ulation of N-type calcium channels by ORL1 receptors. Nat Neurosci $7: 118-125$.

Bisogno T, Melck D, Bobrov MY, Gretskaya NM, Bezuglov VV, De Petrocellis L, Di Marzo V (2000) N-acyl-dopamines: novel synthetic $\mathrm{CB}(1)$ cannabinoid-receptor ligands and inhibitors of anandamide inactivation with cannabimimetic activity in vitro and in vivo. Biochem J 351:817-824.

Bourinet E, Alloui A, Monteil A, Barrère C, Couette B, Poirot O, Pages A, McRory J, Snutch TP, Eschalier A, Nargeot J (2005) Silencing of the Cav3.2 T-type calcium channel gene in sensory neurons demonstrates its major role in nociception. EMBO J 24:315-324.

Bradshaw HB, Walker JM (2005) The expanding field of cannabimimetic and related lipid mediators. Br J Pharmacol 144:459-465.

Bradshaw HB, Rimmerman N, Krey JF, Walker JM (2006) Sex and hormonal cycle differences in rat brain levels of pain-related cannabimimetic lipid mediators. Am J Physiol Regul Integr Comp Physiol 291:R349R358.

Burstein S (2008) The elmiric acids: biologically active anandamide analogs. Neuropharmacology 55:1259-1264.

Burstein SH, Huang SM, Petros TJ, Rossetti RG, Walker JM, Zurier RB (2002) Regulation of anandamide tissue levels by $\mathrm{N}$-arachidonylglycine. Biochem Pharmacol 64:1147-1150.

Chemin J, Monteil A, Perez-Reyes E, Nargeot J, Lory P (2001) Direct inhibition of T-type calcium channels by the endogenous cannabinoid anandamide. EMBO J 20:7033-7040.

Chemin J, Nargeot J, Lory P (2002) Neuronal T-type alpha 1H calcium channels induce neuritogenesis and expression of high-voltage-activated calcium channels in the NG108-15 cell line. J Neurosci 22:6856-6862.

Chemin J, Traboulsie A, Lory P (2006) Molecular pathways underlying the modulation of T-type calcium channels by neurotransmitters and hormones. Cell Calcium 40:121-134.

Chemin J, Nargeot J, Lory P (2007a) Chemical determinants involved in anandamide-induced inhibition of T-type calcium channels. J Biol Chem 282:2314-2323.

Chemin J, Mezghrani A, Bidaud I, Dupasquier S, Marger F, Barrère C, Nargeot J, Lory P (2007b) Temperature-dependent modulation of CaV3 T-type calcium channels by protein kinases $\mathrm{C}$ and $\mathrm{A}$ in mammalian cells. J Biol Chem 282:32710-32718.

Chen CC, Lamping KG, Nuno DW, Barresi R, Prouty SJ, Lavoie JL, Cribbs LL, England SK, Sigmund CD, Weiss RM, Williamson RA, Hill JA, Campbell KP (2003) Abnormal coronary function in mice deficient in alphalH T-type Ca2+ channels. Science 302:1416-1418.

Choi S, Na HS, Kim J, Lee J, Lee S, Kim D, Park J, Chen CC, Campbell KP, Shin HS (2007) Attenuated pain responses in mice lacking $\mathrm{Ca}(\mathrm{V}) 3.2$ T-type channels. Genes Brain Behav 6:425-431.

Coste B, Crest M, Delmas P (2007) Pharmacological dissection and distribution of NaN/Nav1.9, T-type Ca2 + currents, and mechanically activated cation currents in different populations of DRG neurons. J Gen Physiol 129:57-77.

De Petrocellis L, Davis JB, Di Marzo V (2001) Palmitoylethanolamide enhances anandamide stimulation of human vanilloid VR1 receptors. FEBS Lett 506:253-256.

De Petrocellis L, Di Marzo V (2009) Role of endocannabinoids and endovanilloids in $\mathrm{Ca}(2+)$ signalling. Cell Calcium 45:611-624.

Deutsch DG, Chin SA (1993) Enzymatic synthesis and degradation of anandamide, a cannabinoid receptor agonist. Biochem Pharmacol 46:791-796.

Devane WA, Hanus L, Breuer A, Pertwee RG, Stevenson LA, Griffin G, Gibson D, Mandelbaum A, Etinger A, Mechoulam R (1992) Isolation and structure of a brain constituent that binds to the cannabinoid receptor. Science 258:1946-1949.

Guo J, Williams DJ, Ikeda SR (2008) N-arachidonoyl L-serine, a putative endocannabinoid, alters the activation of $\mathrm{N}$-type $\mathrm{Ca} 2+$ channels in sympathetic neurons. J Neurophysiol 100:1147-1151.

Hildebrand ME, David LS, Hamid J, Mulatz K, Garcia E, Zamponi GW, Snutch TP (2007) Selective inhibition of Cav3.3 T-type calcium channels by Galphaq/11-coupled muscarinic acetylcholine receptors. J Biol Chem 282:21043-21055.

Huang SM, Bisogno T, Petros TJ, Chang SY, Zavitsanos PA, Zipkin RE, Sivakumar R, Coop A, Maeda DY, De Petrocellis L, Burstein S, Di Marzo V, Walker JM (2001) Identification of a new class of molecules, the arachidonyl amino acids, and characterization of one member that inhibits pain. J Biol Chem 276:42639-42644.

Huang SM, Bisogno T, Trevisani M, Al-Hayani A, De Petrocellis L, Fezza F, Tognetto M, Petros TJ, Krey JF, Chu CJ, Miller JD, Davies SN, Geppetti P, Walker JM, Di Marzo V (2002) An endogenous capsaicin-like substance with high potency at recombinant and native vanilloid VR1 receptors. Proc Natl Acad Sci U S A 99:8400-8405.

Iftinca M, Hamid J, Chen L, Varela D, Tadayonnejad R, Altier C, Turner RW, Zamponi GW (2007) Regulation of T-type calcium channels by Rhoassociated kinase. Nat Neurosci 10:854-860.

Julius D, Basbaum AI (2001) Molecular mechanisms of nociception. Nature 413:203-210.

Kathuria S, Gaetani S, Fegley D, Valiño F, Duranti A, Tontini A, Mor M, Tarzia G, La Rana G, Calignano A, Giustino A, Tattoli M, Palmery M, Cuomo V, Piomelli D (2003) Modulation of anxiety through blockade of anandamide hydrolysis. Nat Med 9:76-81.

Kim D, Song I, Keum S, Lee T, Jeong MJ, Kim SS, McEnery MW, Shin HS (2001) Lack of the burst firing of thalamocortical relay neurons and resistance to absence seizures in mice lacking alpha(1G) T-type $\mathrm{Ca}(2+)$ channels. Neuron 31:35-45.

Kohno M, Hasegawa H, Inoue A, Muraoka M, Miyazaki T, Oka K, Yasukawa M (2006) Identification of $\mathrm{N}$-arachidonylglycine as the endogenous ligand for orphan G-protein-coupled receptor GPR18. Biochem Biophys Res Commun 347:827-832.

Lee J, Kim D, Shin HS (2004) Lack of delta waves and sleep disturbances during non-rapid eye movement sleep in mice lacking alpha1G-subunit of T-type calcium channels. Proc Natl Acad Sci U S A 101:18195-18199.

Maeda Y, Aoki Y, Sekiguchi F, Matsunami M, Takahashi T, Nishikawa H, Kawabata A (2009) Hyperalgesia induced by spinal and peripheral hydrogen sulfide: evidence for involvement of Cav3.2 T-type calcium channels. Pain 142:127-132.

Maingret F, Patel AJ, Lazdunski M, Honoré E (2001) The endocannabinoid anandamide is a direct and selective blocker of the background $\mathrm{K}(+)$ channel TASK-1. EMBO J 20:47-54.

Mangoni ME, Traboulsie A, Leoni AL, Couette B, Marger L, Le Quang K, Kupfer E, Cohen-Solal A, Vilar J, Shin HS, Escande D, Charpentier F, Nargeot J, Lory P (2006) Bradycardia and slowing of the atrioventricular conduction in mice lacking CaV3.1/alpha1G T-type calcium channels. Circ Res 98:1422-1430.

Milman G, Maor Y, Abu-Lafi S, Horowitz M, Gallily R, Batkai S, Mo FM, Offertaler L, Pacher P, Kunos G, Mechoulam R (2006) N-arachidonoyl L-serine, an endocannabinoid-like brain constituent with vasodilatory properties. Proc Natl Acad Sci U S A 103:2428-2433.

Nelson MT, Joksovic PM, Perez-Reyes E, Todorovic SM (2005) The endogenous redox agent $\mathrm{L}$-cysteine induces $\mathrm{T}$-type $\mathrm{Ca}^{2+}$ channel-dependent sensitization of a novel subpopulation of rat peripheral nociceptors. J Neurosci 25:8766-8775.

Nelson MT, Woo J, Kang HW, Vitko I, Barrett PQ, Perez-Reyes E, Lee JH, Shin HS, Todorovic SM (2007a) Reducing agents sensitize C-type nociceptors by relieving high-affinity zinc inhibition of T-type calcium channels. J Neurosci 27:8250-8260.

Nelson MT, Joksovic PM, Su P, Kang HW, Van Deusen A, Baumgart JP, David LS, Snutch TP, Barrett PQ, Lee JH, Zorumski CF, Perez-Reyes E, Todorovic SM (2007b) Molecular mechanisms of subtype-specific inhibition of neuronal T-type calcium channels by ascorbate. J Neurosci 27:12577-12583.

Oh DY, Yoon JM, Moon MJ, Hwang JI, Choe H, Lee JY, Kim JI, Kim S, Rhim H, O’Dell DK, Walker JM, Na HS, Lee MG, Kwon HB, Kim K, Seong JY (2008) Identification of farnesyl pyrophosphate and N-arachidonylglycine as endogenous ligands for GPR92. J Biol Chem 283:21054-21064.

Park JY, Kang HW, Moon HJ, Huh SU, Jeong SW, Soldatov NM, Lee JH (2006) Activation of protein kinase C augments T-type Ca2+ channel activity without changing channel surface density. J Physiol 577:513-523.

Perez-Reyes E (2003) Molecular physiology of low-voltage-activated t-type calcium channels. Physiol Rev 83:117-161.

Prusakiewicz JJ, Turman MV, Vila A, Ball HL, Al-Mestarihi AH, Di Marzo V, Marnett LJ (2007) Oxidative metabolism of lipoamino acids and vanilloids by lipoxygenases and cyclooxygenases. Arch Biochem Biophys 464:260-268.

Ross HR, Napier I, Connor M (2008) Inhibition of recombinant human T-type calcium channels by Delta9-tetrahydrocannabinol and cannabidiol. J Biol Chem 283:16124-16134. 
Ross HR, Gilmore AJ, Connor M (2009) Inhibition of human recombinant T-type calcium channels by the endocannabinoid $\mathrm{N}$-arachidonoyl dopamine. Br J Pharmacol 156:740-750.

Saghatelian A, McKinney MK, Bandell M, Patapoutian A, Cravatt BF (2006) A FAAH-regulated class of $\mathrm{N}$-acyl taurines that activates TRP ion channels. Biochemistry 45:9007-9015.

Sheskin T, Hanus L, Slager J, Vogel Z, Mechoulam R (1997) Structural requirements for binding of anandamide-type compounds to the brain cannabinoid receptor. J Med Chem 40:659-667.

Succar R, Mitchell VA, Vaughan CW (2007) Actions of N-arachidonylglycine in a rat inflammatory pain model. Mol Pain 3:24.

Tao J, Hildebrand ME, Liao P, Liang MC, Tan G, Li S, Snutch TP, Soong TW (2008) Activation of corticotropin-releasing factor receptor 1 selectively inhibits CaV3.2 T-type calcium channels. Mol Pharmacol 73:1596-1609.

Todorovic SM, Jevtovic-Todorovic V, Meyenburg A, Mennerick S, PerezReyes E, Romano C, Olney JW, Zorumski CF (2001) Redox modulation of T-type calcium channels in rat peripheral nociceptors. Neuron 31:75-85.

Traboulsie A, Chemin J, Chevalier M, Quignard JF, Nargeot J, Lory P (2007) Subunit-specific modulation of T-type calcium channels by zinc. J Physiol 578:159-171.

Triggle DJ (1992) Calcium-channel antagonists: mechanisms of action, vascular selectivities, and clinical relevance. Cleve Clin J Med 59:617-627.

van der Stelt M, Di Marzo V (2005) Anandamide as an intracellular messenger regulating ion channel activity. Prostaglandins Other Lipid Mediat 77:111-122.
Vuong LA, Mitchell VA, Vaughan CW (2008) Actions of N-arachidonylglycine in a rat neuropathic pain model. Neuropharmacology 54:189193.

Wiles AL, Pearlman RJ, Rosvall M, Aubrey KR, Vandenberg RJ (2006) $\mathrm{N}$-Arachidonyl-glycine inhibits the glycine transporter, GLYT2a. J Neurochem 99:781-786.

Williams JR, Khandoga AL, Goyal P, Fells JI, Perygin DH, Siess W, Parrill AL, Tigyi G, Fujiwara Y (2009) Unique ligand selectivity of the GPR92/LPA5 lysophosphatidate receptor indicates role in human platelet activation. J Biol Chem 284:17304-17319.

Wolfe JT, Wang H, Howard J, Garrison JC, Barrett PQ (2003) T-type calcium channel regulation by specific $\mathrm{G}$-protein betagamma subunits. $\mathrm{Na}$ ture 424:209-213.

Wood JN, Boorman JP, Okuse K, Baker MD (2004) Voltage-gated sodium channels and pain pathways. J Neurobiol 61:55-71.

Yang Z, Aubrey KR, Alroy I, Harvey RJ, Vandenberg RJ, Lynch JW (2008) Subunit-specific modulation of glycine receptors by cannabinoids and $\mathrm{N}$-arachidonyl-glycine. Biochem Pharmacol 76:1014-1023.

Yin H, Chu A, Li W, Wang B, Shelton F, Otero F, Nguyen DG, Caldwell JS Chen YA (2009) Lipid G protein-coupled receptor ligand identification using beta-arrestin PathHunter assay. J Biol Chem 284:12328-12338.

Zimmermann M (1983) Ethical guidelines for investigations of experimental pain in conscious animals. Pain 16:109-110.

Zygmunt PM, Petersson J, Andersson DA, Chuang H, Sørgård M, Di Marzo V, Julius D, Högestätt ED (1999) Vanilloid receptors on sensory nerves mediate the vasodilator action of anandamine. Nature 400:452-457. 